
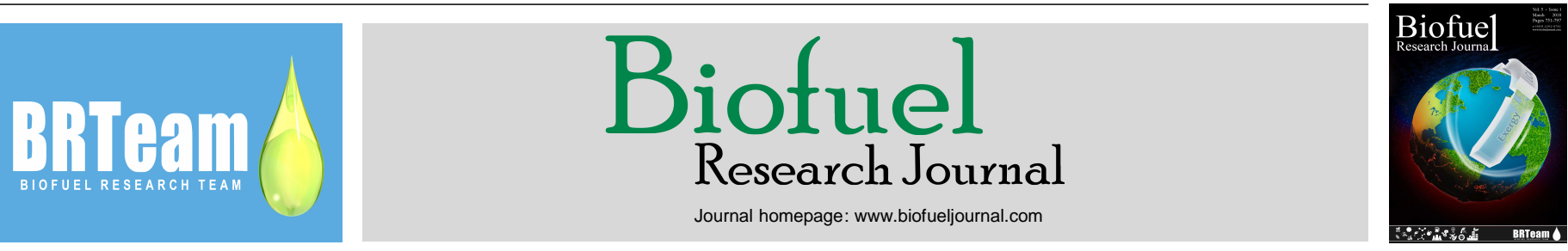

Original Research Paper

\title{
Bacterial laminarinase for application in ethanol production from brown algae Sargassum sp. using halotolerant yeast
}

\author{
C.M.T. Perez ${ }^{1,2, *}$, I.G. Pajares ${ }^{3}$, V.A. Alcantara ${ }^{3}$, J.F. Simbahan ${ }^{3,4}$ \\ ${ }^{I}$ Graduate School, University of the Philippines Los Banos, College, Laguna 4031, Philippines.
}

${ }^{2}$ Hiroshima University, 739-0046 Hiroshima Prefecture, Higashihirosima, Kagamiyama, 1 Chome- 3- 2, Japan.

${ }^{3}$ National Institute of Molecular Biology and Biotechnology (BIOTECH), University of the Philippines Los Banos, College, Laguna 4031, Philippines.

${ }^{4}$ Institute of Biology College of Science, University of the Philippines Diliman, Quezon City, Philippines.

\section{HIGHLIGHTS}

$>$ Laminarinase enzyme was produced and partially purified from Bacillus sp.

$>$ Halotolerant yeasts were screened, partially characterized, and were later used in fermentation of saccharified algal biomass.

$>$ The laboratory-produced laminarinase was able to hydrolyze algal biomass to simple sugars, proving that it can be used for saccharification.

$>$ Ethanol produced in saccharification treatments using a combination of cellulase and laminarinase was higher implying a possible synergistic effect between the two enzymes.

\section{GRAPHICAL ABSTRACT}

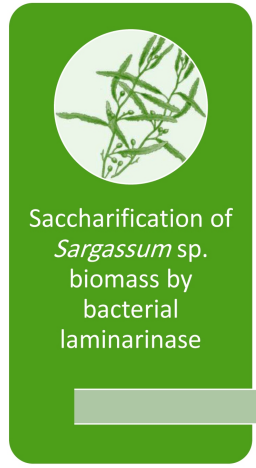

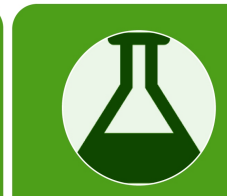

Fermentation of algal hydrolysate using halotolerant yeast

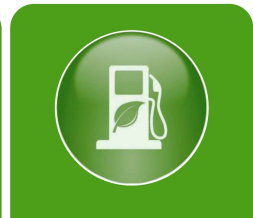

Production of $3^{\text {rd }}$ generation bioethanol
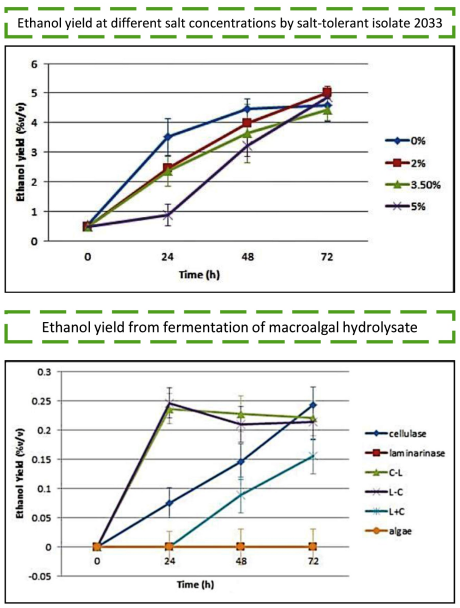

\section{ARTICLE INFO}

\section{Article history:}

Received 20 January 2018

Received in revised form 20 February 2018

Accepted 20 February 2018

Available online 1 March 2018

\section{Keywords:}

Bioethanol

Cellulase

Laminarinase

Macroalgae

Halotolerant yeast

\begin{abstract}
Macroalgae are known to have many industrial applications, with current research targeting the potential of macroalgal biomass as feedstock in production of biofuels. Marine algal biomass is rich in storage carbohydrates, laminarin, and cellulose, which can be converted to fermentable sugars using appropriate enzymes, for fermentation to ethanol. This study focused on ethanol production from macroalgae using only enzymatic treatment for saccharification of algal biomass. This involved the isolation and identification of cellulase and laminarinase-producing microorganisms from mangrove area in the Philippines and production of partially purified enzymes for algal biomass saccharification. Results showed that the partially purified laminarinase produced from Bacillus sp. was capable of hydrolyzing the laminarin present in the macroalage. Fermentation of the algal hydrolysate yielded only small amount of ethanol due to lack of other pre-treatment methods, however, it was observed that higher ethanol was produced in saccharific ation treatments using a combination of cellulase and laminarinase which implies a possible synergistic effect between the two enzymes.
\end{abstract}

() 2018 BRTeam. All rights reserved.

* Corresponding author at: Tel.: +817075658797

E-mail address: cmtperez26@ gmail.com, cmtperez26@hiroshima-u.ac.jp

Please cite this article as: Perez C.M.T., Pajares I.G., Alcantara V.A., Simbahan J.F. Detection of bacterial laminarinase activity for possible application in ethanol production from algal hydrolysate of brown algae, Sargassum sp., using halotolerant yeast. Biofuel Research Journal 17 (2018) 792-797. DOI: 10.18331/BRJ2018.5.1.6 


\section{Introduction}

Third generation biofuels are fuels derived from algae and have gained increased attention, as they are believed to hold potentials to address the "food $v s$. fuel" conflict caused by first generation biofuels as well as the limitations of second generation biofuels. Macroalgae are ideal feedstocks due to their very high biomass yield, and also because they do not compete with agricultural crops for land and water resources. Many algal species are able to grow in marine water, salt water, and even municipal wastewaters. Due to high photon conversion efficiency of macroalgae, biomass can be rapidly synthesized through assimilation of abundant natural resources including sunlight, carbon dioxide, and inorganic nutrients. This results in significantly higher algal production than that of terrestrial biomass. Another reason is that algae lack lignin which is needed in plants to provide structural support. Absence of lignin allows for easier depolymerisation compared to lignocellulosic biomass (Wei et al., 2013).

Macroalgae are made up of several polysaccharides such as laminarin, mannitol, cellulose, fucoidan, and alginate. Except for cellulose and laminarin, all other polysaccharides have been utilized industrially. Mannitol, a sugar alcohol, has wide medical applications such as in osmotherapy and in food products where it is used as a sweetener for individuals suffering from diabetes due to its low glycemic index. Fucoidan, a sulfated polysaccharide, is widely used as dietary supplement. Alginate has the most industrial importance. Its utilization ranges from textile printing to pharmaceutical, medical, and food applications (Mesnildrey, 2012).

Laminarin and cellulose are polysaccharides which can be converted to simple sugars, i.e., glucose, that may act as substrate for yeast fermentation. In a study conducted by Borines et al. (2013), pre-treatment methods with the use of high sulfuric acid concentration and extremely high temperature were employed before saccharification and fermentation of the algal biomass. These pre-treatment methods may inhibit the subsequent microbial fermentation through production of inhibitory compounds. Therefore, enzymatic pretreatment using cellulase and laminarinase for saccharification of algal biomass seems more beneficial than its chemical counterparts such as acid conversion. However, the problem lies with the high cost and unavailability of commercial laminarinase enzyme. Development of locally produced bacterial laminarinase may provide the solution by reducing production cost. The enzyme can be readily produced using laminarin as substrate following a relatively simple method for laminarin extraction (Black et al., 1951) from seaweeds.

The Philippine Biofuels Act 2006 states that oil companies are required to use biofuels in all liquid fuels used for motor and engines and this has been mandated since February 2009. With this, all gasoline in the country is blended with at least 5-10\% ethanol. On the other hand, according to the Department of Energy, petroleum product imports increased by $17.7 \%$ in 2017 compared to the year before, and are expected to continue to rise until 2020. Hence, researchers are striving to find alternative sources for ethanol production rather than crops (i.e., corn, sugarcane, and wheat) which are bound to be used as food or feed. One alternative is the use of macroalgae as feedstock. Among the literature available (Yeon et al., 2010; Borines et al., 2013; Tamayo and Del Rosario, 2014), Sargassum is the macroalgae commonly used for ethanol production due to its abundant distribution worldwide. Even though it has been found to have other economic importance, it is necessary to assess whether its potential as a fuel source would offer greater benefits.

Accordingly, the main objective of the present study was to determine if the laboratory-produced, laminarinase, would be capable of algal biomass hydrolysis for possible application in ethanol production. Throughout this study, efforts were also put into screening and identification of marine bacterial isolates capable of laminarinase production, as well as into screening and partial characterization of halotolerant yeast strains.

\section{Materials and Methods}

\subsection{Macroalgal biomass}

Sargassum sp. was harvested from Nasugbu, Batangas, Philippines, in the summer of 2013. It was quickly washed with tap water to remove salts and other impurities and was air-dried. Subsequently, samples were oven-dried overnight at a temperature not more than $70{ }^{\circ} \mathrm{C}$ (Memmert Drying Oven). Oven-dried samples were ground to a particle size of not more than $4 \mathrm{~mm}$ using a Thomas Wiley Mill. Samples were then submitted to the Central Analytical
Service Laboratory, BIOTECH UPLB, for proximate analysis as well as cellulose content and percent salt analysis.

\subsection{Extraction of laminarin}

Crude laminarin was extracted using the modified protocol of Black et al. (1951) for the extraction of cold water-soluble laminarin. Hydrochloric acid $(0.10 \mathrm{M})$ (Scharlau) was added to ground samples of Sargassum sp. and incubated in a cold water bath $\left(20^{\circ} \mathrm{C}\right)$ for $2 \mathrm{~h}$. The solution was filtered using filter cloth and the weed residues were washed with $0.05 \mathrm{M} \mathrm{HCl}$. Ethanol (95\%) (Emsure ${ }^{\mathrm{R}}$ ) was added to the combined filtrate and washing to precipitate the laminarin. The precipitate was then washed with ethanol (70\%) and air-dried. Initial and final weights of the laminarin were obtained to determine percent recovery.

\subsection{Determination of total sugar by phenol-sulfuric acid assay}

Total sugar content of the extracted laminarin was determined by phenol-sulfuric assay. Briefly, $1 \mathrm{~mL}$ of $5 \%$ phenol was added to different concentrations of glucose solution prepared from $1 \mathrm{mg} / \mathrm{mL}$ stock or to the diluted sample. Then, $5 \mathrm{~mL}$ of concentrated sulfuric acid was added to the solution and mixed. Once the tubes had cooled to room temperature the absorbance was read at $490 \mathrm{~nm}$ using a UV-vis spectrophotometer (UV1700 PharmaSpec) (Dubois et al., 1956)

\subsection{Screening for bacterial enzymes and halotolerant yeast strain}

Water and soil samples were obtained from different locations along mangrove areas in Lian, Batangas, Philippines, in April of 2013. Samples were collected and placed in sterile containers. Bacterial strains were isolated by placing $10 \mathrm{~g}$ of the sample in $90 \mathrm{~mL}$ of $0.85 \%$ saline solution to make $10^{-1}$ dilution. Dilutions of up to $10^{-3}$ were prepared and $0.1 \mathrm{~mL}$ of each dilution was plated on Marine Agar 55 g. $\mathrm{L}^{-1}$ (Difco).

\subsubsection{Detection and screening for laminarinase enzyme}

Detection of laminarinase activity of the isolates was determined by qualitative plate assay. Pure cultures of the isolates were inoculated into Laminarin Agar and incubated for 7 d. Growth on Laminarin Agar (0.1 g.L ${ }^{1}$ laminarin, 0.1 g. $\mathrm{L}^{-1} \mathrm{MgSO}_{4}, 0.1$ g.L $\mathrm{L}^{-1} \mathrm{NaCl}, 0.1$ g.L $\mathrm{L}^{-1} \mathrm{CaCl}_{2}, 2$ g.L $\mathrm{L}^{-1}$ $\left(\mathrm{NH}_{4}\right)_{2} \mathrm{SO}_{4}, 0.5$ g.L $\mathrm{L}^{-1} \mathrm{KH}_{2} \mathrm{PO}_{4}, 0.5 \mathrm{~mL} \cdot \mathrm{L}^{-1}$ mineral solution, $0.5 \mathrm{~mL} \cdot \mathrm{L}^{-1}$ vitamin solution, and 15 g. $\mathrm{L}^{-1}$ agar) was taken as positive laminarindegrading isolates. Mineral solution was prepared by adding the following components to $1 \mathrm{~L}$ distilled water: $3 \mathrm{~g} \mathrm{FeSO}_{4} \cdot 7 \mathrm{H}_{2} \mathrm{O}, 0.01 \mathrm{~g} \mathrm{H}_{3} \mathrm{BO}_{3}, 0.01 \mathrm{~g}$ $\mathrm{NaMoO}_{4} \cdot 2 \mathrm{H}_{2} \mathrm{O}, 0.02 \mathrm{~g} \mathrm{MnSO}_{4} \cdot \mathrm{H}_{2} \mathrm{O}, 0.01 \mathrm{~g} \mathrm{CuSO}_{4} \cdot 5 \mathrm{H}_{2} \mathrm{O}, 0.01 \mathrm{~g} \mathrm{ZnSO}_{4}$, and $0.5 \mathrm{~g}$ EDTA. Vitamin solution was prepared by adding the following components in $1 \mathrm{~L}$ distilled water: $0.2 \mathrm{~g}$ nicotinic acid, $0.4 \mathrm{~g}$ thiamine $\mathrm{HCl}$, $0.2 \mathrm{~g}$ nicotinamide, and $0.008 \mathrm{~g}$ biotin. Mineral and vitamin solution were filter sterilized before addition to the media.

Confirmation and quantification of laminarinase activity was also done by performing 3,5-Dinitro-2-hydroxybenzoic acid (DNS) assay. Isolates positive in the qualitative assay were grown in Enzyme Production Medium containing laminarin as sole carbon source for $5 \mathrm{~d}$ after which the cells were harvested by centrifugation (Beckman Coulter. Allegra X-15R Centrifuge) at $12000 \times \mathrm{g}$ for $30 \mathrm{~min}$ at $4{ }^{\circ} \mathrm{C}$. Supernatant (crude enzyme) was collected and stored at $-20{ }^{\circ} \mathrm{C}$ until enzyme activity assay. In assaying for enzyme activity, reaction mixture containing $0.5 \mathrm{~mL}$ of supernatant, $0.5 \mathrm{~mL}$ of $0.05 \mathrm{M}$ citrate, and $0.5 \%$ laminarin was prepared. The reaction mixture was then incubated at $37{ }^{\circ} \mathrm{C}$ for $30 \mathrm{~min}$ after which $3 \mathrm{~mL}$ of DNS reagent was added to the supernatant and the solution was boiled for 5-15 min until the color turned red brown. Activity was measured by determining the increase in reducing sugar as glucose (Chesters and Bull, 1963).

\subsubsection{Screening for halotolerant yeast}

The following yeast strains were obtained from the Biotechnology for Industry, Energy and Environment Program (BIEEP) Laboratory, BIOTECH, UP Los Banos: TB3, 2030, 2010, 2022, 2015, 2008, 2013, 2021, and 2033. The yeasts were grown on Yeast Extract Peptone Dextrose 
(YEPD) medium containing different concentrations of $\mathrm{NaCl}(0 \%, 2 \%, 3.5 \%$, and $5 \%$ ) for screening for halotolerance.

Candidate strains were tested for ethanol production under different $\mathrm{NaCl}$ concentrations. Yeast cultures were inoculated onto YEPD slants and incubated for $24 \mathrm{~h}$ after which growth was transferred to YEPD broth containing 5\% glucose and incubated for 16- $18 \mathrm{~h}$ with shaking. Cultures with an OD value of 1.0 were then inoculated to YEPD fermentation media containing different $\mathrm{NaCl}$ concentrations $(0 \%, 2 \%, 3.5 \%$, and $5 \%)$. These cultures were then incubated without shaking for $48 \mathrm{~h}$. Sampling was done at 0,24 , and $48 \mathrm{~h}$ and the samples were analyzed for reducing sugar by DNS assay and ethanol yield by gas chromatography (GC).

\subsection{Production and partial purification of laminarinase}

The bacterial isolate was grown in Enzyme Production Media containing laminarin as sole carbon source for $5 \mathrm{~d}$ with shaking at $25{ }^{\circ} \mathrm{C}$. The cells were separated by centrifugation at $12000 \times \mathrm{g}$ for $30 \mathrm{~min}$ at $4{ }^{\circ} \mathrm{C}$. The supernatant was again centrifuged (Beckman Coulter. Allegra X-15R Centrifuge) at $12000 \times \mathrm{g}$ for $30 \mathrm{~min}$ at $4{ }^{\circ} \mathrm{C}$ and stored at $-20{ }^{\circ} \mathrm{C}$ until further analysis (Alderkamp et al., 2007). The crude enzyme was partially purified by ammonium sulfate precipitation. Ammonium sulfate was slowly added to the enzyme with stirring until $85 \%$ saturation was reached. The solution was centrifuged and the pellet was separated from the supernatant where it was resuspended in $15 \mathrm{~mL}$ of Tris$\mathrm{HCl}$ buffer. The partially purified enzyme was then assayed using analytical grade laminarin and ground algae as substrates, following laminarinase assay procedure previously outlined (Chester and Bulls, 1963).

\subsection{Saccharification of algal biomass using crude enzymes}

Crude enzymes were added to saccharify algal biomass and amount of fermentable sugars liberated was measured. Algal samples were weighed based on individual moisture content and calculated cellulose content such that it provided $0.10 \mathrm{~g}$ of cellulose on a dry basis. Samples were mixed with $250 \mathrm{~mL}$ of $0.1 \mathrm{M}$ citrate buffer, enzyme concentration based on saccharification treatments, and sterile distilled water such that the total reaction volume would be $500 \mathrm{~mL}$.

The enzymes used were either the crude cellulase obtained from Enzyme Laboratory, BIOTECH UPLB or Accelerase $1500^{\mathrm{TM}}$ (Genencor Company, USA) and the partially purified laminarinase enzyme. The following treatments were employed: cellulase alone, laminarinase alone, cellulase + laminarinase, laminarinase then cellulase, cellulase then laminarinase. The samples were placed in an incubator shaker for $2 \mathrm{~d}$ at $50{ }^{\circ} \mathrm{C}$ and sampling was performed at $0,1,3,6,9,12,18,24$, and $48 \mathrm{~h}$. Samples were analysed for reducing sugar. After hydrolysis, the residues were separated from the liquid by centrifugation and decantation.

\subsection{Fermentation of algal biomass using halotolerant yeast}

Inoculum build-up of isolate 2033 was prepared as mentioned in screening for halotolerant yeast strains. Cultures with OD values of 0.1 were inoculated onto fermentation medium. Fermentation medium was prepared containing the hydrolysate mentioned in the saccharification of algal biomass, amended with

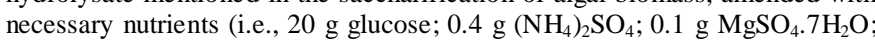
$0.7 \mathrm{~g} \mathrm{KH}_{2} \mathrm{PO}_{4}$, and $400 \mathrm{~mL} \mathrm{H}_{2} \mathrm{O}$ ). The incubation was done at room temperature, without shaking for $48 \mathrm{~h}$. After fermentation, samples were withdrawn at 0,24 , and $48 \mathrm{~h}$ and analysed for reducing sugar and ethanol content.

\subsection{Statistical analysis}

Analysis of Variance (ANOVA) was performed to determine significance of treatments. Tukey's Range Test was performed to compare pairs of means and to remove familywise error rate in the test.

\section{Results and Discussion}

\subsection{Macroalgal biomass}

The results of proximate analysis and percent salt analysis of the Sargassum sp. are shown in Table 1 . The computed values for proximate analysis were comparable to the results of Borines et al. (2013). The percent ash was $15.38 \pm .05$, which is within the range of ash content of $12-36 \%$ (Ross et al., 2008) but quite low compared to the study of Kim et al. (2011) with $46 \%$ ash content for Sargassum fulvellum.

Table 1.

Proximate analysis and salt analysis of dried Sargassum sp.

\begin{tabular}{lcccccc}
\hline & $\begin{array}{c}\text { Moisture } \\
(\boldsymbol{\%})\end{array}$ & $\begin{array}{c}\text { Ash } \\
(\boldsymbol{\%})\end{array}$ & $\begin{array}{c}\text { Crude fat } \\
(\boldsymbol{\%})\end{array}$ & $\begin{array}{c}\text { Crude } \\
\text { protein }(\boldsymbol{\%})\end{array}$ & $\begin{array}{c}\text { Crude } \\
\text { fiber }(\boldsymbol{\%})\end{array}$ & $\begin{array}{c}\text { Salt } \\
(\boldsymbol{\%})\end{array}$ \\
\hline $\begin{array}{l}\text { Dried } \\
\text { seaweed }\end{array}$ & $14.31 \pm 0.08$ & $15.38 \pm 0.5$ & $0.37 \pm 0.03$ & $6.50 \pm 0.22$ & $7.56 \pm 0.21$ & 4.4 \\
\hline
\end{tabular}

The fiber and protein components were found to be $7.56 \pm 0.21 \%$ and $6.50 \pm 0.22 \%$, respectively. These values are quite low in comparison to the study of Murugaiyan et al. (2012) where the protein component of Sargassum wightii was $16.59 \pm 0.86 \%$. Lipid component was also low, only amounting to $0.37 \pm 0.03 \%$.

Table 2 shows the total carbohydrate and cellulose content of the Sargassum sp.. The carbohydrate component was at $55.88 \%$. In various studies, carbohydrate content ranged from $25.5 \pm 1.37 \%$ for $S$. wighti (Murugaiyan et al., 2012) to $16.8 \pm 0.7 \%$ for Sargassum longifolium (Narasimman and Murugaiyan, 2012), and $41.81 \%$ for Sargassum spp. (Borines et al., 2013). The difference between the carbohydrate content of algae is due to the seasonal variation, as affected by environmental factors such as water temperature, salinity, light, and nutrients (John et al., 2011). Sargassum sp. was harvested in the summer of 2013 and the high carbohydrate obtained corresponds to the findings of Schiener et al. (2014) that carbohydrates in brown seaweeds were found to accumulate during summer and autumn.

Table 2.

Structural composition of Sargassum sp.

\begin{tabular}{lcccc}
\hline & $\begin{array}{c}\text { Total carbohydrate } \\
(\boldsymbol{\%})\end{array}$ & $\begin{array}{c}\text { Alpha-Cellulose } \\
(\boldsymbol{\%})\end{array}$ & $\begin{array}{c}\text { Hemicellulose } \\
\mathbf{( \% )}\end{array}$ & $\begin{array}{c}\text { Holocellulose } \\
(\boldsymbol{\%})\end{array}$ \\
\hline $\begin{array}{l}\text { Dried } \\
\text { seaweed }\end{array}$ & 55.88 & 30.33 & 14.39 & 44.72 \\
\hline
\end{tabular}

The holocellulose content of Sargassum sp., was found to be $44.72 \%$ (Table 2). Alpha-cellulose amounted to $30.33 \%$ while hemicellulose was $14.39 \%$. Borines et al. (2013) mentioned that if the percent hemicellulose content of the sample is higher than alpha-cellulose, there is a need for pretreatment. Since the percent hemicellulose content of the sample was lower than that of alpha-cellulose, this suggested that pre-treatment was not necessary.

\subsection{Extraction of laminarin}

Laminarin is crucial in assaying for laminarinase activity, however, due to its scarcity in the market, the laminarin used in the study was extracted directly from Sargassum sp. As seen in Table 3, for every initial weight of $100 \mathrm{~g}$ ground Sargassum sp., $9.7 \mathrm{~g}$ of dried laminarin was obtained, giving a percent recovery of $9.7 \%$. Total sugar measured by phenol sulphuric assay was $4 \mathrm{mg} \cdot \mathrm{mL}^{-1}$.

Table 3.

Physical properties of the extracted laminarin.

\begin{tabular}{ll}
\hline Parameters & Values \\
\hline Initial weight & $100 \mathrm{~g}$ \\
Final weight & $9.7 \mathrm{~g}$ \\
Recovery (\%) & $9.7 \%$ \\
Total sugar & $4 \mathrm{mg} \cdot \mathrm{mL}^{-1}$ \\
\hline
\end{tabular}




\subsection{Screening for bacterial enzymes and halotolerant yeast strain}

\subsubsection{Screening and production of laminarinase enzyme}

Twelve bacterial isolates were purified from the mangrove samples and were subjected to laminarinase plate assay. The isolates that were able to grow on laminarin agar were $8 \mathrm{~A}, 8 \mathrm{D}$, and $14 \mathrm{P}$. Crude laminarinase enzymes were then prepared from each of the isolates and assayed for enzymatic activity using the DNS reducing sugar method. Laminarinase activity, as measured by the amount of reducing sugar liberated in $\mathrm{mg}$. $\mathrm{mL}^{-1}$, ranged from 0.36 to 0.46 . Since the enzyme activity of the three isolates were not significantly different from each other, isolate $8 \mathrm{D}$ was chosen for bacterial laminarinase production because it exhibited favorable growth in cultures. Crude laminarinase produced by isolate $8 \mathrm{D}$ was further purified using ammonium sulphate precipitation. Table 4 indicates the activity of the partially purified laminarinase using $0.5 \%$ pure laminarin and ground algae as substrate. The partially purified laminarinase was able to liberate $0.54 \mathrm{mg} \cdot \mathrm{mL}^{-1}$ of glucose from pure laminarin and 0.33 $\mathrm{mg} \cdot \mathrm{mL}^{-1}$ of glucose from ground seaweed as substrate. The ability of partially purified laminarinase to hydrolyse the laminarin present in the untreated algal biomass indicated that it could be used for saccharification.

Table 4.

Amount of reducing sugar $\left(\mathrm{mg} \cdot \mathrm{mL}^{-1}\right)$ liberated upon addition of partially purified laminarinase enzyme using $0.5 \%$ pure laminarin and ground algae as substrate.

\begin{tabular}{ll}
\hline Substrate $(\mathbf{0 . 5 \%})$ & Reducing Sugar $\left(\mathbf{m g} \cdot \mathbf{m L}^{-1}\right)$ \\
\hline Pure laminarin & $0.54^{\mathrm{a}^{*}}$ \\
Ground Sargassum & $0.33^{\mathrm{b}}$ \\
\hline * Same letters are not significantly different $(\mathrm{p}<0.05)$
\end{tabular}

* Same letters are not significantly different $(\mathrm{p}<0.05)$

\subsubsection{Screening for halotolerant yeast}

Yeasts in the BIEEP laboratory collection were screened for salt tolerance since algal biomass is expected to contain high amounts of salt. Salt concentration of the sea water is at $3.5 \%$, thus yeast strains that are able to grow at $3.5 \%$ and beyond are candidates for ethanol production from macroalgae. Three out of nine isolates, i.e., isolates 2010, 2021, and 2033, were capable of growing at 3.5-5\% salt. Their growth on YEPD Medium containing varying concentrations of $\mathrm{NaCl}$ is shown in Figure 1. HBY3, an industrial strain was included in the screening. Furthermore, ethanol production, cell count, reducing sugar, and ethanol yield were also measured at $0,24,48$, and $72 \mathrm{~h}$ (Fig. 2). Ethanol was produced by all isolates after $72 \mathrm{~h}$. Isolate 2033 was able to produce the highest amount of ethanol at different $\mathrm{NaCl}$ concentrations tested indicating that it is tolerant to $\mathrm{NaCl}$.

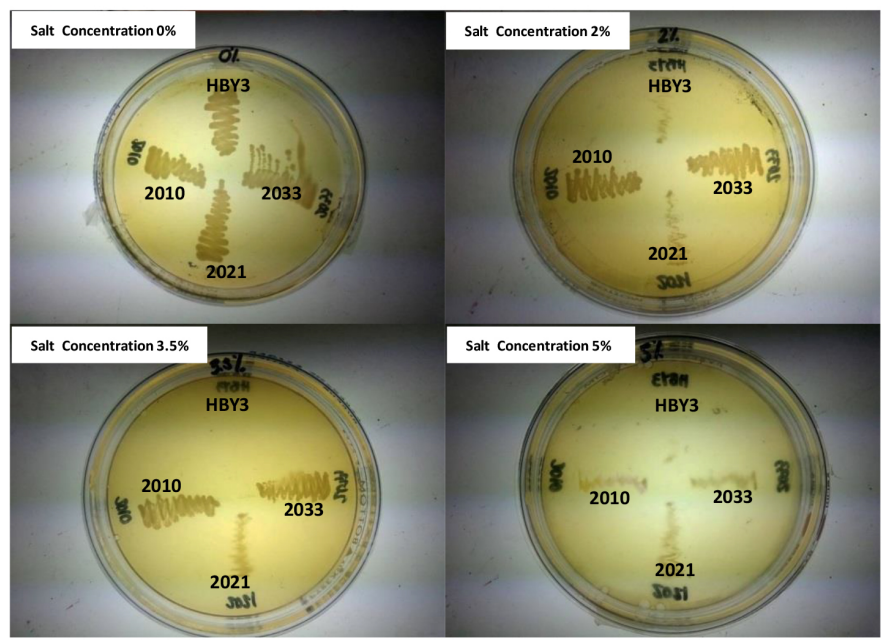

Fig.1. Growth of yeasts strains (HBY3, 2010, 2021, and 2033) in YEPD media supplemented with different salt concentrations $(0,2,3.5$, and $5 \%)$.
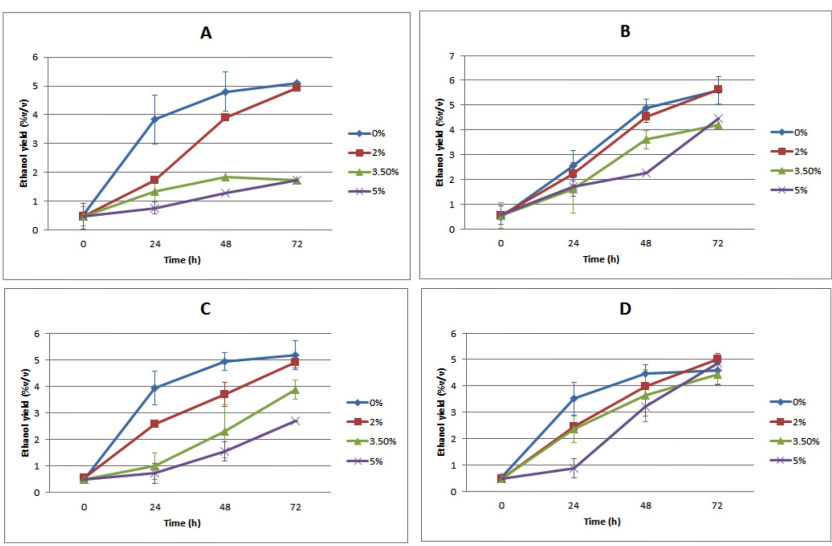

Fig.2. Ethanol yield (\%v/v) at increasing $\mathrm{NaCl}$ concentrations after $0,24,48$, and $72 \mathrm{~h}$ of sampling; A) HBY3, (B) 2010, (C) 2021, (D) 2033; Percentage at the right side of graph refers to $\% \mathrm{NaCl}$ concentration (values are expressed as means \pm standard deviation, $\mathrm{n}=3$ ).

Figure 3 shows the amount of reducing sugar $\left(\mathrm{mg} \cdot \mathrm{mL}^{-1}\right)$ liberated at each sampling point. A decreasing trend can be observed for all $\mathrm{NaCl}$ concentrations corresponding to the increase in ethanol production since the reducing sugar liberated was being used as substrate for production of ethanol (Fig. 2).

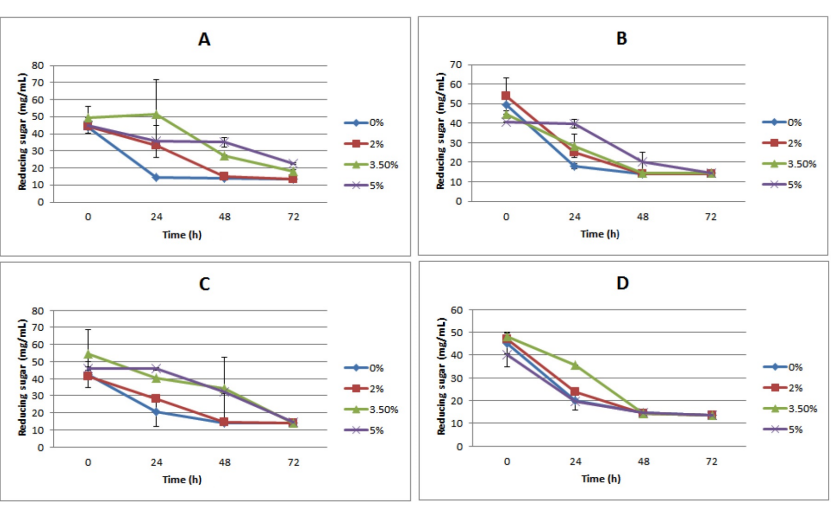

Fig.3. Amount of reducing sugar (mg.mL ${ }^{-1}$ ) after $0,24,48$, and $72 \mathrm{~h}$ of sampling; (A) HBY3, (B) 2010 , (C) 2021 , (D) 2033; Percentage at the right side of graph refers to $\% \mathrm{NaCl}$ concentration (values are expressed as means \pm standard deviation, $n=3$ ).

\subsection{Saccharification of algal biomass using crude enzymes}

Saccharification of algal biomass was performed using crude laminarinase produced by Isolate $8 \mathrm{D}$ and Accelerase $1500^{\mathrm{TM}}$, a commercial cellulase enzyme or crude cellulase obtained from the Enzyme Laboratory at BIOTECH, UPLB. In other studies, like that of Borines et al. (2013) and Lee et al. (2013), pre-treatment methods using high or low acid and heat, were done before saccharification. Acid pre-treatment was employed in order to release more glucose, generally from laminarin. However, use of acid and heat for pre-treatment can inhibit microbial fermentation through production of furfurals, thus lowering bioethanol yield of brown algae. In this study, no acid and heat pre-treatment was carried out and instead, employed the use of partially purified laminarinase and cellulase enzymes.

Figure 4 shows the amount of glucose liberated upon saccharification of ground algae using different combinations of the enzymes. The 

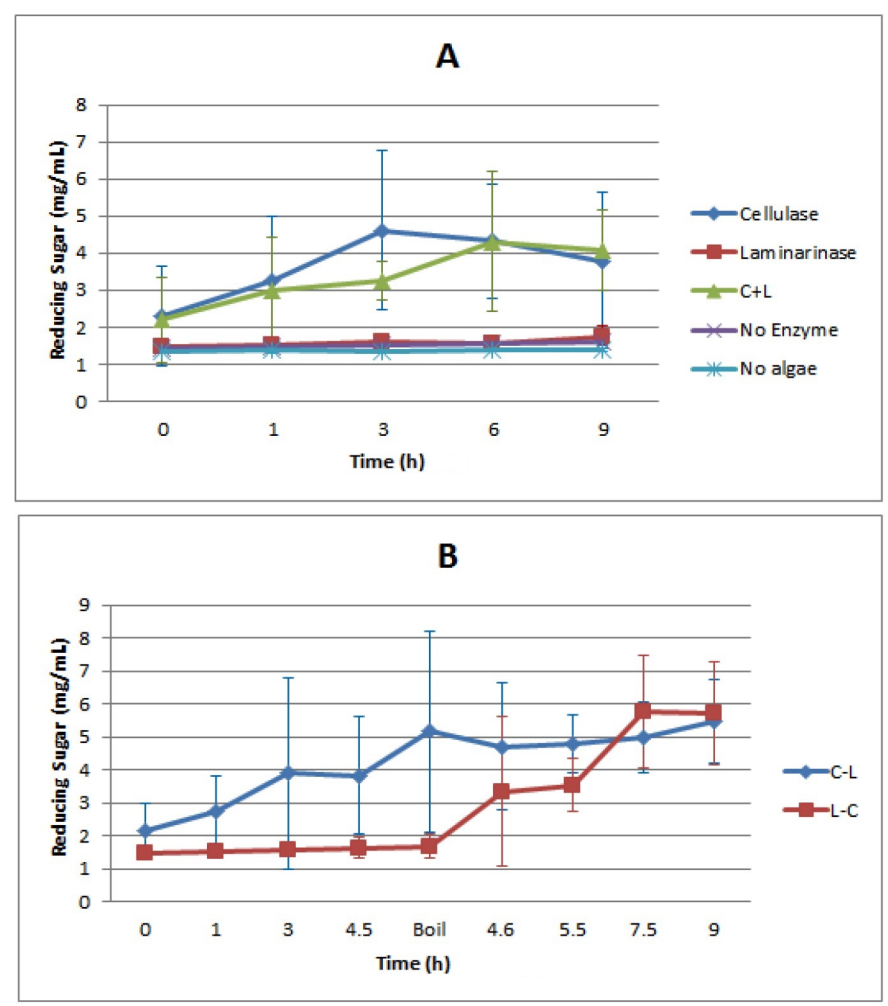

Fig.4. Amount of reducing sugar $\left(\mathrm{mg} \cdot \mathrm{mL}^{-1}\right)$ released upon saccharification of algal biomass using laminarinase and Commercial Cellulase (Accelerase). A) Treatments using laminarinase alone, cellulase alone, laminarinase and cellulase and controls; and B) Treatments using cellulase then laminarinase and laminarinase then cellulase. (values are expressed as means \pm standard deviation, $\mathrm{n}=3$ ).

treatments were as follows: commercial cellulase (C) alone, crude laminarinase (L) alone, commercial cellulase and crude laminarinase added together. For sequential treatment one enzyme was added before the other. The first enzyme was incubated with the algal biomass for $4.5 \mathrm{~h}$ then boiling was done to stop the activity of the first enzyme before adding the second enzyme and further incubation for another $4.5 \mathrm{~h}$. For treatment with commercial cellulase alone, an increase in reducing sugar was observed from $3.28 \mathrm{mg} \cdot \mathrm{mL}^{-1}$ at $0 \mathrm{~h}$ to 5.11 mg. $\mathrm{mL}^{-1}$ after $9 \mathrm{~h}$ of incubation. For treatment with crude laminarinase alone, a very slight increase in reducing sugar, from $1.54 \mathrm{mg} \cdot \mathrm{mL}^{-1}$ at $0 \mathrm{~h}$ to 1.97 mg. $\mathrm{mL}^{-1}$ after $9 \mathrm{~h}$ was observed. Higher amounts of sugars were liberated for treatment with combination of both enzymes. Treatment with commercial cellulase and crude laminarinase together showed $5.65 \mathrm{mg} \cdot \mathrm{mL}^{-1}$ reducing sugar was released after $9 \mathrm{~h}$. For treatment with cellulase then laminarinase, 5.09 $\mathrm{mg} \cdot \mathrm{mL}^{-1}$ was released upon addition of cellulase, followed by a slight increase in glucose upon addition of laminarinase with $6.36 \mathrm{mg} . \mathrm{mL}^{-1}$ reducing sugar. For treatment with laminarinase followed by cellulase, $1.86 \mathrm{mg} \cdot \mathrm{mL}^{-1}$ was released upon addition of laminarinase and $6.83 \mathrm{mg} \cdot \mathrm{mL}^{-1}$ glucose upon addition of cellulase. The high amount of glucose released was from the activity of commercial cellulase (Accelerase) and not the crude laminarinase.

In another experiment, the amount of crude laminarinase was increased, the incubation time was extended and the crude cellulase obtained from BIOTECH was used. The same enzyme combinations were used as in the previous experiment. Treatment with crude cellulase alone showed $2.10 \mathrm{mg} \cdot \mathrm{mL}^{-1}$ glucose released after $48 \mathrm{~h}$. For treatment with crude laminarinase only, 1.58 mg. $\mathrm{mL}^{-1}$ glucose was released after $48 \mathrm{~h}$. This shows that the activity of a crude enzyme is very limited. For the treatment with crude laminarinase then crude cellulase, $1.80 \mathrm{mg} \cdot \mathrm{mL}^{-1}$ was released upon addition of laminarinase while 2.64 $\mathrm{mg} \cdot \mathrm{mL}^{-1}$ was released upon addition of cellulase.

\subsection{Fermentation of algal biomass using halotolerant yeast}

The algal hydrolysates from saccharification using the commercial cellulase and crude laminarinase were fermented using the best halotolerant yeast, i.e.,

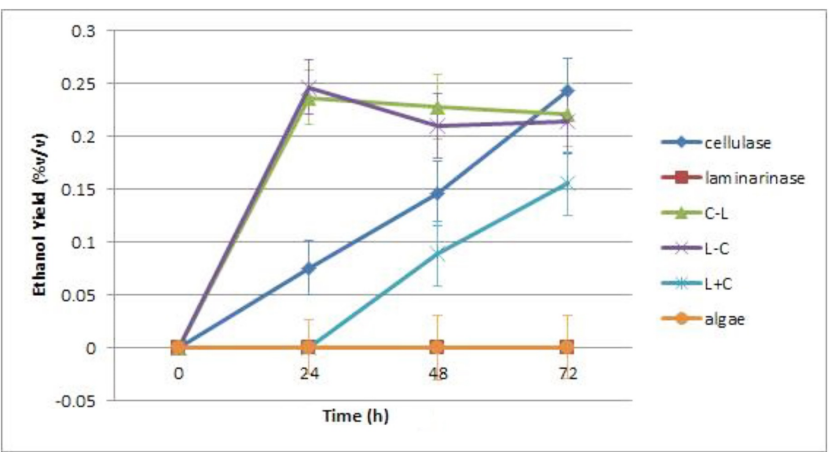

Fig.5. Ethanol yield $(\% \mathrm{v} / \mathrm{v})$ after $0,24,48$, and $72 \mathrm{~h}$ of sampling from fermentation of macroalgal hydrolysate.

isolate 2033. Figure 5 shows the ethanol yield from fermentation of the hydrolysates. Highest ethanol production was obtained after $24 \mathrm{~h}$ from the algal biomass saccharified using sequential addition of cellulase and laminarinase irrespective of which enzyme was added first (L-C and C-L, Fig. 5). Isolate 2033 incubated in the biomass saccharified with cellulase alone reached a similar ethanol yield only after $72 \mathrm{~h}$ of incubation. The biomass saccharified with combined cellulase and laminarinase produced around $0.15 \%$ ethanol. No ethanol was produced from the biomass treated with crude laminarinase enzyme alone since the reducing sugar released was too low for the yeast to ferment into ethanol. On the other hand, use of laminarinase in conjunction with cellulase was shown to result in an enhanced effect in producing higher amounts of ethanol compared to the treatments with individual enzymes. Figure 6 on the other hand shows the amount of reducing sugar $\left(\mathrm{mg} \cdot \mathrm{mL}^{-1}\right)$ in the medium at different time intervals during fermentation. A decreasing trend can be observed for all treatments corresponding to ethanol fermentation.

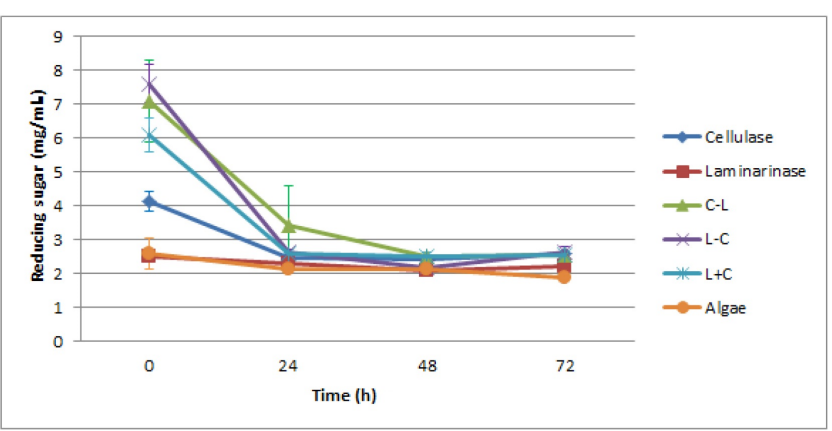

Fig.6. Amount of reducing sugar $\left(\mathrm{mg} \cdot \mathrm{mL}^{-1}\right)$ after $0,24,48$, and $72 \mathrm{~h}$ of sampling from fermentation of macroalgal hydrolysate with different enzymatic treatment (values are expressed as means \pm standard deviation, $\mathrm{n}=3$ ).

\section{Conclusions}

This study was able to screen and identify marine bacterial isolates capable of laminarinase production and to produce partially purified laminarinase enzyme from Bacillus sp. Halotolerant yeasts were screened, partially characterized and were later used in fermentation of saccharified algal biomass. The laboratory-produced laminarinase was able to hydrolyze algal biomass to simple sugars, proving that it can be used for saccharification. Ethanol produced in saccharification treatments using a combination of cellulase and laminarinase were higher implying a possible 
synergistic effect between the two enzymes. Overall, low yield of ethanol for all treatments implied poor saccharification of biomass using enzymatic treatment alone. Further studies should be directed toward optimization of enzyme production by Bacillus sp., conditions for saccharification, and synergistic effect of enzymes. This is the first report exploiting the use of laminarinase from a local isolate as an alternative to acid and heat pre-treatment for bioethanol production from macroalgal biomass.

\section{Acknowledgments}

We would like to thank the following people and laboratories for their valuable contributions in the study:

- Biotechnology for Industry, Energy and Environment Program, BIOTECH UPLB

- Central Analytical Service Laboratory, BIOTECH UPLB

- Francisco Elegado, Ph. D.

- Johnry Maloles, MSc.

\section{References}

[1] Alderkamp, A.C., Van Rijssel, M., Bolhuis, H., 2007. Characterization of marine bacteria and the activityof their enzyme systems involved in degradation of the algal storage glucan laminarin. FEMS Microbiol. Ecol. 59(1), 108-117.

[2] Black, W.A.P., Cornhill, W.J., Dewar, E.T., Woodward, F.N., 1951. Manufacture of algal chemicals. III. Laboratory-scale isolation of laminarin from brown marine algae. J. Chem. Appl. Technol. 1(11), 505517.

[3] Borines, M.G., de Leon, R.L., Cuello, J.L., 2013. Bioethanol production from the macroalgae Sargassum spp. Bioresour. Technol. 138, $22-29$.

[4] Chesters, C.G.C., Bull, A.T., 1963. The enzymatic degradation of laminarin. 1. the distribution of laminarinase among micro-organisms. Biochem. J. 86(1), 28-31

[5] Dombek, K.M., Ingram, L.O., 1987. Ethanol production during batch fermentation with Saccharomyces cerevisiae: changes in glycolytic enzymes and internal pH. Appl. Environ. Microbiol. 53(6), 1286-1291.
[6] Dubois, M., Gilles, K.A., Hamilton, J.K., Rebers, P.T., Smith, F., 1956. Colorimetric method for determination of sugars and related substances. Anal. Chem. 28(3), 350-356.

[7] Gusakov, A.V., Kondratyeva, E.G., Sinitsyn, A.P., 2011. Comparison of two methods for assaying reducing sugars in the determination of carbohydrase activities. Int. J. Anal. Chem. 2011.

[8] John, R.P., Anisha, G.S., Nampoothiri, K.M., Pandey, A., 2011. Micro and macroalgal biomass: a renewable source for bioethanol. Bioresour. Technol. 102(1), 186-193.

[9] Kim, N.J., Li, H., Jung, K., Chang, H.N., Lee, P.C., 2011. Ethanol production from marine algal hydrolysates using Escherichia coli KO11. Bioresour. Technol. 102(16), 7466-7469.

[10] Madigan, M.T., Martinko, P., Dunlap, V., Clark, D.P., 2012. Brock biology of microorganisms, $13^{\text {th }}$ ed. San Francisco, CA: Pearson/Benjamin Cummings.

[11] Mesnildrey, L., Jacob, C., Frangoudes, K., Reunavot, M., Lesueur, M., 2012. Seaweed industry in France report. Interreg program NETALGAE. Les publications du Pôlehalieutique.

[12] Miller, G.L., 1959. Use of dinitrosaiicyiic acid reagent for determination of reducing sugar. Anal. Chem. 31(3), 426-428.

[13] Murugaiyan, K., Narasimman, S., Anatharaman, P., 2012. Proximate composition of marine macroalgae from Seeniappa Dharka, Gulf of Mannar region, Tamil Nadu. Int. J. Res. Marine Sci. 1(1), 1-3.

[14] Narasimman, S., 2012. Proximate composition of certain selected marine macro-algae form mandapam coastal region (Gulf of Mannar), southeast coast of Tamil Nadu. Int. J. Pharm. Biol. Arch. 3(4), 918 921.

[15] Nielsen, S.S., 2010. Phenol-sulfuric acid method for total carbohydrates. Food Anal. Lab. Manual. 47-53.

[16] Ross, A.B., Jones, J.M., Kubacki, M.L., Bridgeman, T., 2008. Classification of macroalgae as fuel and its thermochemical behaviour. Bioresour. Technol. 99(14), 6494-6504.

[17] Singh, A., Olsen, S.I., 2011. A critical review of biochemical conversion, sustainability and life cycle assessment of algal biofuels. Appl. Energy. 88(10), 3548-3555.

[18] Wei, N., Quarterman, J., Jin, Y.S., 2013. Marine macroalgae: an untapped resource for producing fuels and chemicals. Trends Biotechnol. 31(2), 70-77. 